\title{
Translational Research for Improving the Care of Familial Hypercholesterolemia: The "Ten Countries Study" and Beyond
}

\author{
Gerald F Watts ${ }^{1,2}$, Phillip YA Ding*, Peter George ${ }^{3}$, Martin S Hagger, 5, 6 , Miao Hu ${ }^{7}$, Jie Lin ${ }^{8}$, \\ Kah Lin Khoo*, A David Marais ${ }^{9}$, Takashi Miida ${ }^{10}$, Hapizah M Nawawi ${ }^{11}$, Jing Pang ${ }^{1}$, Jeong Euy Park ${ }^{12}$, \\ Lourdes B Gonzalez-Santos ${ }^{13}$, Ta-Chen Su ${ }^{14}$, Thanh Huong Truong ${ }^{15}$, Raul D Santos ${ }^{16}$, Handrean Soran ${ }^{17}$, \\ Shizuya Yamashita ${ }^{18,19}$ and Brian Tomlinson" for the members of the "Ten Countries Study"
}

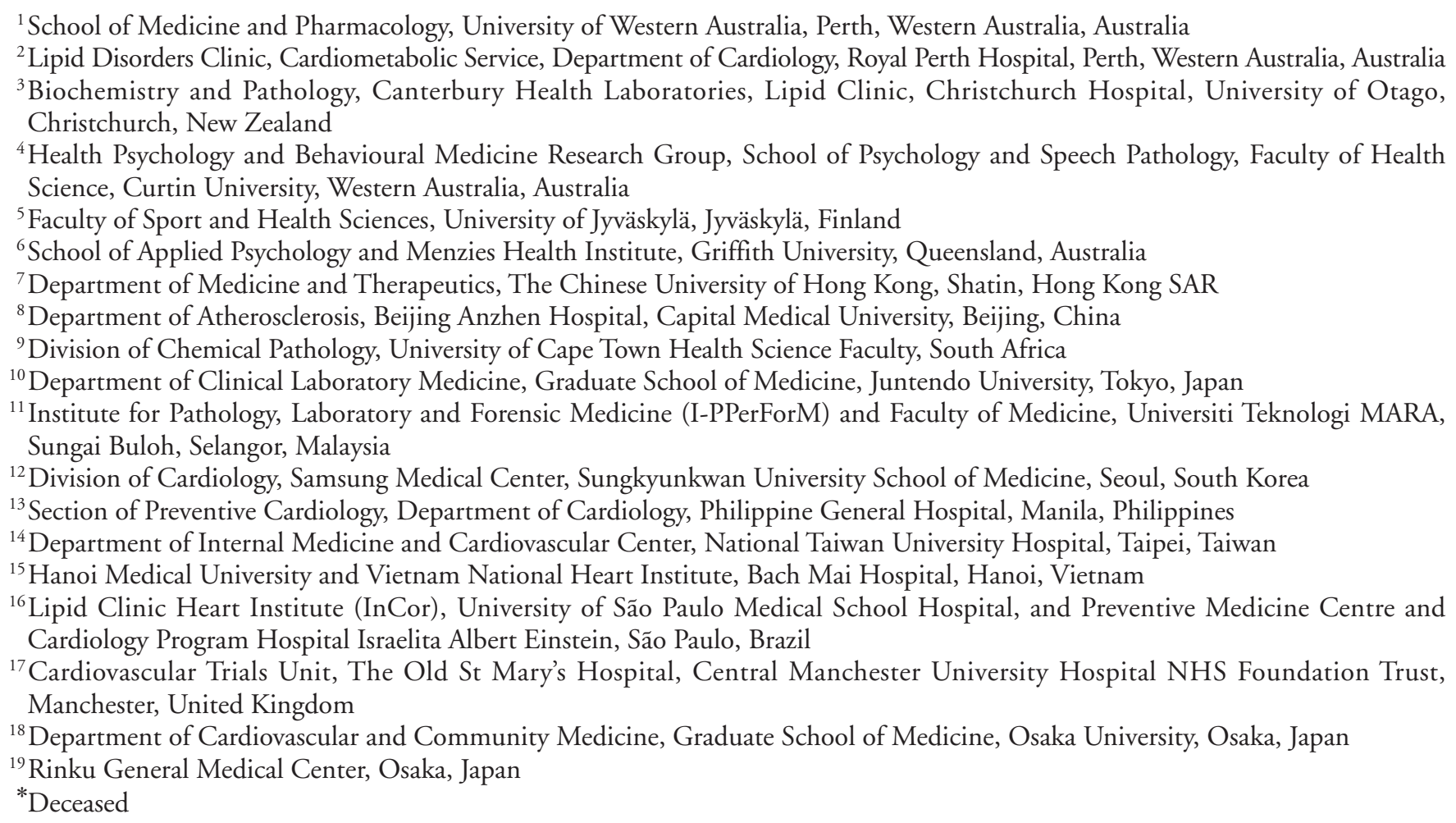

Familial hypercholesterolemia $(\mathrm{FH})$ is the most common and serious form of inherited hyperlipidaemia. Dominantly inherited with high penetrance, untreated FH leads to premature death from coronary artery disease due to accelerated atherosclerosis from birth. Despite its importance, there is still a major shortfall in awareness, detection and treatment of $\mathrm{FH}$ worldwide. International models of care for $\mathrm{FH}$ have recently been published, but their effective implementation requires the garnering of more knowledge about the condition. The "Ten Countries Study" aims to investigate diagnostic, epidemiological and service aspects, as well as physician practices and patient experiences of $\mathrm{FH}$ in several countries in the Asia-Pacific Region and the Southern Hemisphere. Five observational studies are being undertaken that will systematically investigate the following aspects of $\mathrm{FH}$ : the phenotypic predictors of low-density lipoprotein receptor mutations, the point prevalence in available community populations, current knowledge and clinical practices among primary care physicians, availability and utilisation of services and facilities, and patient perceptions and personal experiences of the condition. The information gathered will inform better clinical practice and will enable the development of country-specific models of care for FH.

Key words: Familial hypercholesterolaemia, Asia-Pacific, Translational research 


\section{Introduction}

Familial hypercholesterolemia $(\mathrm{FH})$ is the most common and serious form of inherited hyperlipidemia $^{1)}$. It is dominantly inherited and has a high phenotypic penetrance. If untreated, $\mathrm{FH}$ leads to premature death from coronary heart disease (CHD) in many families ${ }^{2)}$. FH accelerates atherosclerotic cardiovascular disease (ACVD), particularly coronary artery disease. The pathogenesis of FH results from mutations in several genes that impair the catabolism of low-density lipoprotein (LDL) particles; the most common of these are in the LDL-receptor $(L D L R)$ gene, which can affect receptor synthesis, transport, binding, internalization, and recycling. Mutations in the genes encoding apolipoprotein $\mathrm{B}(A P O B)$, the receptor ligand, and proprotein convertase subtilisin/ kexin type 9 (PCSK9), a binding protein that degrades LDLR, are less frequently implicated.

The prevalence of heterozygous $\mathrm{FH}$ is commonly estimated to be $1: 500^{3)}$ in unselected community populations. However, the prevalence is high in populations subject to a "founder gene effect" such as the Afrikaners, Lithuanian Jews, Christian Lebanese, French Canadian, and the Finns ${ }^{4}$. The prevalence of true homozygous $\mathrm{FH}$ is considered to be 1 in $1,000,000^{5)}$. The forgoing population prevalence data have been recently questioned and updated ${ }^{6}$. The frequency of $\mathrm{FH}$ is also higher in clinical populations with premature CHD, such as among patients in coronary care units $^{7)}$. Under-detection of $\mathrm{FH}$ is a global problem, and there are estimated to be at least 15 million people with FH worldwide ${ }^{8)}$. Screening enables early evidence-based interventions, such as lifestyle measures and cholesterol-lowering medications, which decrease the risk of ACVD, improves the health of families, and saves lives and health expenditure ${ }^{9,10)}$.

\section{Impetus for the Investigation}

The value of the detection and treatment of $\mathrm{FH}$ is abundantly supported by the outcome of several international cohort studies ${ }^{11-14}$. However, there are significant gaps in knowledge that impede the effective implementation of screening services and care pathways worldwide.

Owing to the very high population density in some Asian countries, Asia is estimated to have the

Address for correspondence: Gerald F Watts, School of Medicine and Pharmacology, University of Western Australia, GPO Box X2213 Perth WA 6847 Australia

E-mail: gerald.watts@uwa.edu.au

Received: April 10, 2016

Accepted for publication: May 16, 2016 largest number of individuals with $\mathrm{FH}$ in the world (Fig. 1). In particular, China and India may have at least 5.2 million affected individuals. Despite this, there are several gaps in knowledge of the phenotypic predictors of mutations, the community prevalence, physician awareness, patients' perceptions, and the availability of health services ${ }^{9,15)}$.

Guidelines on treatment and management of FH have been published by the International FH Foundation $^{9)}$ and endorsed by the Asian-Pacific Society of Atherosclerosis and Vascular Disease ${ }^{16)}$. This provides an early foundation for the development of expert guidelines, essential services, and new models of care in Asian countries. Guidelines and diagnostic criteria for $\mathrm{FH}$ have hitherto been produced by Japan ${ }^{17)}$ and Australasia ${ }^{18)}$; Hong Kong ${ }^{19)}$ and South Korea ${ }^{20)}$ also recently communicated their experiences in managing $\mathrm{FH}$. This is a good start to a long journey.

\section{Core Group and Networks}

The "Ten Countries Study" is being undertaken under the auspices of the FH Australasia Network. The study group was assembled to tackle several country-specific questions in the Asia-Pacific region and the southern hemisphere. However, the increasing communication among centers and the development of new networks have resulted in the recruitment of other centers. Hence, the study group and network currently includes at least 15 countries: Australia, Japan, Hong Kong, China, Taiwan, South Korea, Malaysia, Philippines, Vietnam, Singapore, India, New Zealand, South Africa, Brazil, and the United Kingdom (Fig. 2). The United Kingdom, a country with a highly developed healthcare system and a sophisticated guideline for the care of FH developed by the National Institute for Health and Care Excellence (NICE), will provide benchmark data for international comparison. Further networking has spawned a new association with the FH Studies Collaboration (FHSC) ${ }^{21)}$.

\section{Overarching Aim and Objectives}

The overarching aim of the study is to ultimately improve the care of patients and families with $\mathrm{FH}$ via the following projects that address: (1) the phenotypic predictors of $\mathrm{FH}$ mutations, (2) the point prevalence of $\mathrm{FH}$ in unselected community populations, (3) knowledge and practices of primary care physicians concerning FH, (4) availability and utilization of services and facilities for the care of $\mathrm{FH}$, and (5) patient perceptions and personal experiences of FH (Table 1). These projects are aligned to the $\mathrm{FH}$ research agenda recently proposed in a scientific statement from the 


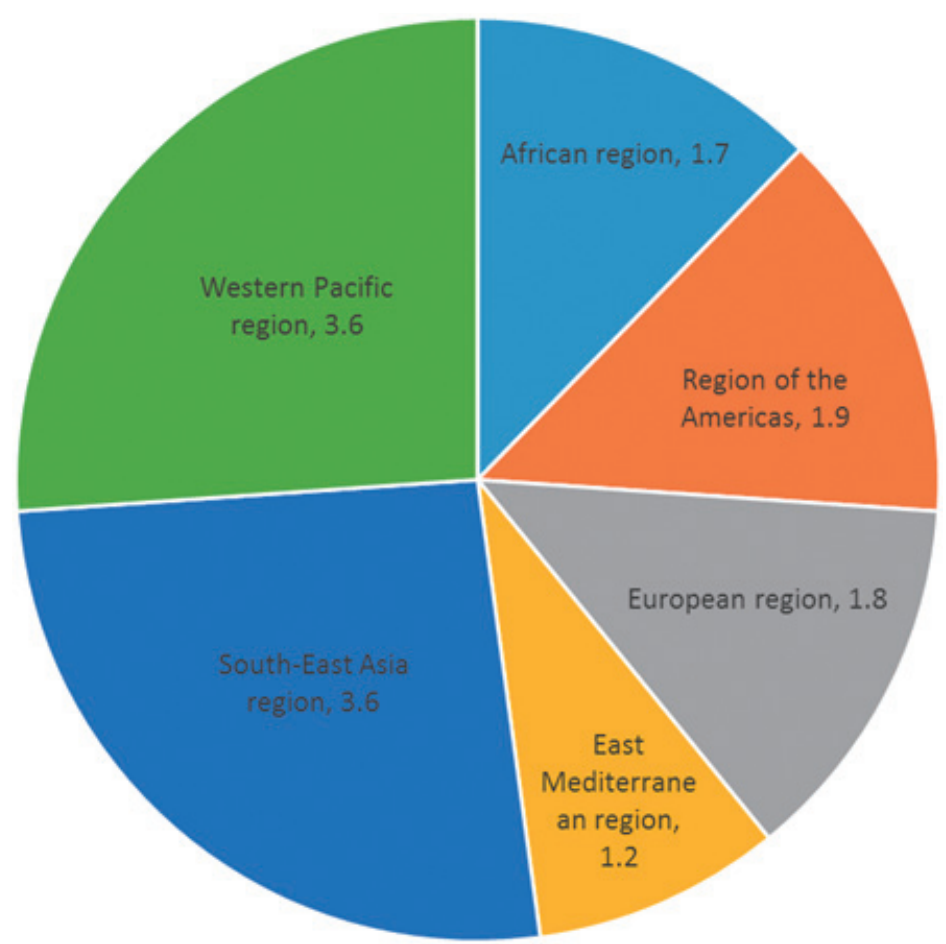

Fig. 1. Estimated number (millions) of individuals with $\mathrm{FH}$ in WHO-defined regions based on the theoretical prevalence of 1:500 ${ }^{3)}$ for heterozygous FH (Adapted from Pang et $a l^{42)}$. At least $50 \%$ of $\mathrm{FH}$ patients in the world are likely to come from Asian countries (included in the Western Pacific region and South-East Asia region).

American Heart Association (Table 2) ${ }^{22)}$.

A related objective of the "Ten Countries Study" is to close gaps in knowledge and awareness of $\mathrm{FH}$ through an educational program utilizing the collective data obtained from the individual studies. This will also more widely facilitate best practices in the care of $\mathrm{FH}$ in the region. Education will be provided by country-specific societies that are members of the International Atherosclerosis Society, with the ultimate objective of creating a network of local healthcare providers with the expertise in clinical lipidology.

\section{Individual Projects}

\section{(1) Screening and Diagnostic Testing: LDL-choles- terol as a Predictor of FH Mutations}

FH specifically elevates plasma LDL-cholesterol concentration owing to the decreased uptake of LDL, mediated by the ligand apoB-100 for the LDL receptor. Diagnostic accuracy relies on identifying a causative mutation ${ }^{1,9,15)}$. Most mutations causing FH occur in the $L D L R$ (encoding low-density lipoprotein receptor) and fewer in $A P O B$ (encoding apolipoprotein $\mathrm{B}$ ) and $P C S K 9$ (encoding proprotein convertase subtili- sin/kexin type 9) ${ }^{1,23,24)}$. The prognostic importance of identifying a genetic mutation causative of $\mathrm{FH}$ in patients with profound hypercholesterolemia in the community has recently been underscored ${ }^{25}$. However, genetic testing is often prohibitively expensive and not commonly available, particularly in primary care and in Asian centers. The diagnostic thresholds of untreated LDL-cholesterol have not been defined in relation to their ability to predict a pathogenic $\mathrm{FH}$ mutation. Phenotypic criteria also require detailed family history and detection of occasionally subtle physical signs, such as arcus cornealis or xanthomata; these may not be easily detectable, and their agedependence invalidates them as criteria for the early detection of $\mathrm{FH}^{9}$, 15, 26). A recent study from South Korea demonstrated that traditional criteria have limited detection power and low specificity for mutations in their population ${ }^{27)}$. This underscores the need for region- or country-specific criteria and guidelines. We aim to inform a first-step screening test for FH, based on LDL-cholesterol measurement, for use in primary care.

The study has involved countries where genetic testing is available for clinical or research purposes 


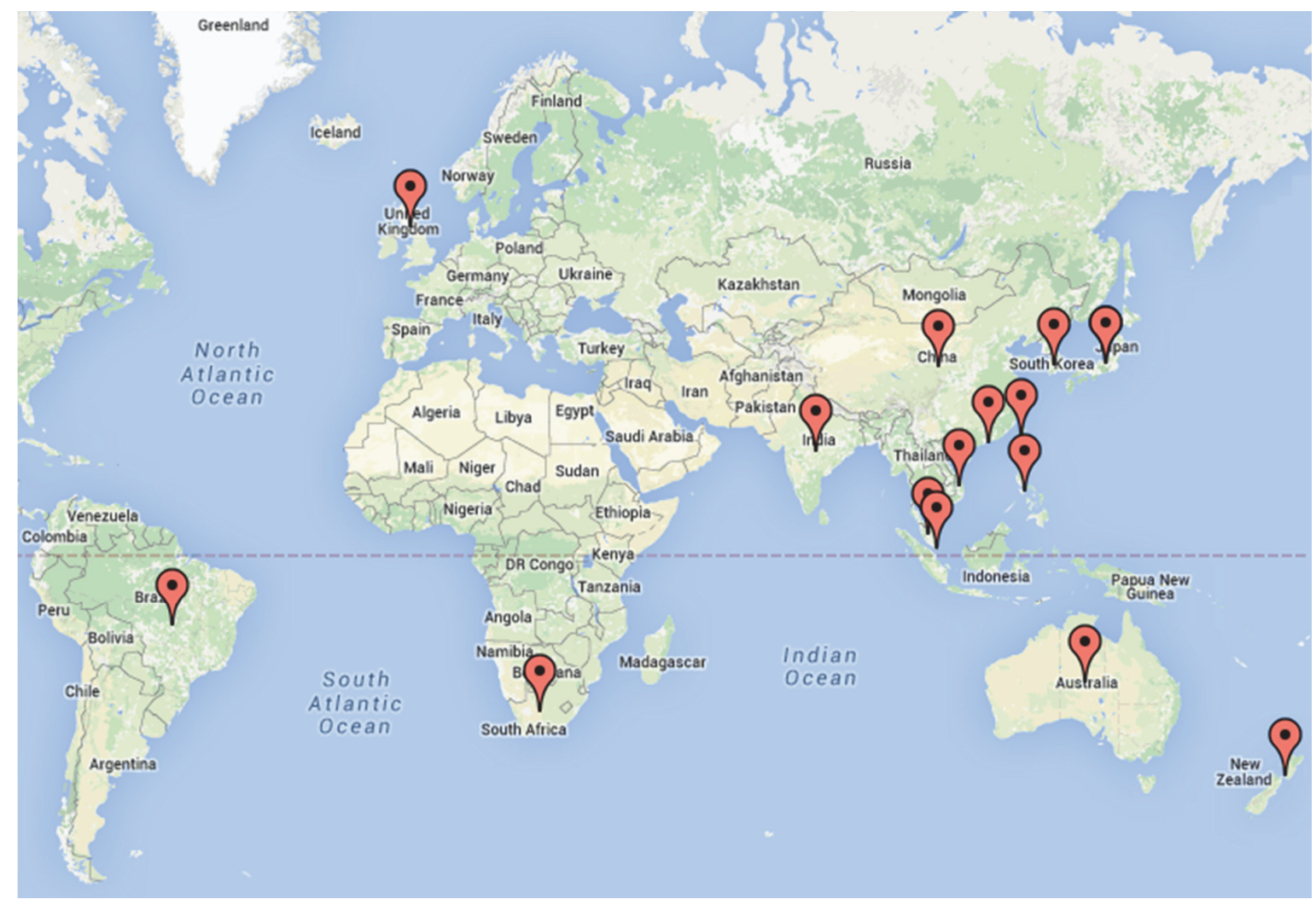

Fig. 2. Map showing the countries currently participating in the "Ten Countries Study."

(Australia, Hong Kong, Brazil, and New Zealand). The cross-sectional investigation aims to select a level of plasma LDL-cholesterol that has the highest sensitivity and specificity in predicting a pathogenic mutation. Adults who have provided informed consent for genetic testing and collection of phenotypic data will mainly be studied. LDL-cholesterol levels from a fasting blood sample at screening will be adjusted if required for the type and dose of cholesterol-lowering drugs $^{28)}$. Mutational analyses for defects in the $L D L R$, $A P O B$, and PCSK9 genes and assessment of pathogenicity have been uniformly performed as described elsewhere ${ }^{18,24,29,30)}$.

The ability of plasma LDL-cholesterol concentrations to predict a genetic variant will be investigated using receiver operator characteristic curves. The best value of LDL-cholesterol for predicting a mutation will be defined as a having a sensitivity $>90 \%$, with the highest corresponding level of specificity and/or the highest sum of sensitivity and specificity. The effect of other variables (such as family and personal history of high cholesterol or coronary heart disease, physical signs, and ethnicity) on the sensitivity and specificity of the LDL-cholesterol threshold will also be tested by multiple logistic regression analysis.

\section{(2) Epidemiology: Prevalence of FH in Community and High-risk Populations}

Excluding rare populations subject to a gene founder effect in whom $\mathrm{FH}$ is particularly common, the community prevalence of $\mathrm{FH}$ is estimated to be 1 in 500, with reports varying from 1 in 200 to 1 in $2000^{2}$. Prevalence data enable the design of screening programs for $\mathrm{FH}$ in the community ${ }^{31}$. We have completed studies in China and Australia, where the prevalence of heterozygous $\mathrm{FH}$ was found to be 1:211$359^{32}$ and 1:229-353 ${ }^{33)}$, respectively, consistent with recent findings from the US ${ }^{34)}$ and Europe ${ }^{35,36)}$. In children from Australia, we also found a frequency of FH of 1 in 267 by LDL-cholesterol and family history criteria ${ }^{37)}$. The apparent higher frequency of $\mathrm{FH}$ in community populations has been well evidenced by two recent studies employing genetic testing ${ }^{25,35)}$. Data from all countries appear to consistently indicate underdiagnosis and under-treatment of $\mathrm{FH}$ across all ages and ethnic groups. The prevalence of $\mathrm{FH}$ in coronary care units is also informative for targeted screening for index cases. In Australia ${ }^{7)}, 14.3 \%$ of coronary patients aged less than 60 years were found to have phenotypic $\mathrm{FH}$. These data concur with reports from Europe ${ }^{38}$. 
Table 1. Summary of the five principal projects comprising in the "Ten Countries Study".

\begin{tabular}{|c|c|c|c|}
\hline $\begin{array}{l}\text { Project } \\
\text { Number }\end{array}$ & Title & Aim & Translational Value \\
\hline 1 & $\begin{array}{l}\text { Plasma LDL-cholesterol as a } \\
\text { predictor of FH mutations }\end{array}$ & $\begin{array}{l}\text { To select a level of plasma LDL-cho- } \\
\text { lesterol that has the highest sensitivity } \\
\text { and specificity in predicting a muta- } \\
\text { tion in different countries. }\end{array}$ & $\begin{array}{l}\text { The data will inform a simple screening test for FH, } \\
\text { based on LDL-cholesterol measurement, for use in } \\
\text { primary care and where genetic testing is not avail- } \\
\text { able. }\end{array}$ \\
\hline 2 & $\begin{array}{l}\text { Prevalence of } \mathrm{FH} \text { in commu- } \\
\text { nity populations }\end{array}$ & $\begin{array}{l}\text { To assess the prevalence of } \mathrm{FH} \text { in adult } \\
\text { and childhood populations. }\end{array}$ & $\begin{array}{l}\text { The data will emphasize the public health problem } \\
\text { presented FH, including the shortfalls in detection } \\
\text { and treatment. This will inform screening programs } \\
\text { for FH in the community. }\end{array}$ \\
\hline 3 & $\begin{array}{l}\text { Knowledge and practices of } \\
\text { Primary Care Physicians } \\
\text { (PCPs) concerning FH }\end{array}$ & $\begin{array}{l}\text { To determine awareness, knowledge } \\
\text { and practices regarding FH in PCPs; } \\
\text { and conduct a comparison across the } \\
\text { centres in the region. }\end{array}$ & $\begin{array}{l}\text { Defining the role of PCPs in the care of FH is essen- } \\
\text { tial for developing multi-disciplinary and integrated } \\
\text { total quality management. Assessing current knowl- } \\
\text { edge and practices is the starting point. The infor- } \\
\text { mation also will be employed to design effective } \\
\text { teaching and training modules for PCPs in the } \\
\text { detection and management of FH. }\end{array}$ \\
\hline 4 & $\begin{array}{l}\text { Comparison of services and } \\
\text { facilities for the care of FH }\end{array}$ & $\begin{array}{l}\text { To describe and compare existing } \\
\text { health services, facilities and resources } \\
\text { for the care in } \mathrm{FH} \text { in the region. }\end{array}$ & $\begin{array}{l}\text { The study will provide international benchmarking } \\
\text { of performance in health care for FH. It will identify } \\
\text { and promote successful strategies within a context } \\
\text { that takes into account cultural, economic and logis- } \\
\text { tic differences and create opportunities for imple- } \\
\text { menting country-specific or region-specific models } \\
\text { of care for FH. }\end{array}$ \\
\hline 5 & $\begin{array}{l}\text { Patient perceptions and per- } \\
\text { sonal experiences of } \mathrm{FH}\end{array}$ & $\begin{array}{l}\text { To investigate the association between } \\
\text { patients' psychological factors and key } \\
\text { behavioural and clinical outcome vari- } \\
\text { ables salient to the management of } \\
\text { FH; and conduct a comparison across } \\
\text { the centres in the region. }\end{array}$ & $\begin{array}{l}\text { The study will identify the key psychological factors } \\
\text { associated with compliance and patient decisions. } \\
\text { The factors can then be used as a basis for behav- } \\
\text { ioural interventions to promote better treatment } \\
\text { compliance and patient decisions. }\end{array}$ \\
\hline
\end{tabular}

\section{(3) Education and Training: Knowledge and Prac- tices of FH Among Physicians}

The majority of people in the community will have contact with their primary care physician (PCP) or family doctor. PCPs can perform absolute cardiovascular risk assessments and are well placed to opportunistically detect $\mathrm{FH}^{39,40)}$. Well controlled and low complexity patients, initially identified in specialist centers, should be transitioned if feasible to primary care for long-term management or for shared care, whereas high complexity patients should be followed up by the specialist service ${ }^{9)}$. The role of primary care in the care of $\mathrm{FH}$ has not been adequately defined. A preliminary study suggested a significant shortfall in awareness, knowledge, and practices among family doctors in the Asia-Pacific region ${ }^{41,42)}$. Defining the role of PCPs in the care of FH is essential for developing multidiscplinary and integrated total quality management. Assessing current knowledge and practices is considered to be the starting point.

In the investigation, a formal questionnaire is being offered to PCPs via cardiovascular education sessions and/or mail lists from the royal colleges (or country equivalent). Completion of the survey is voluntary and anonymous. The survey enquires about the following elements: general familiarity with $\mathrm{FH}$; awareness of national and international guidelines for $\mathrm{FH}$; the clinical description of $\mathrm{FH}$; identification of the typical lipid profile; prevalence and inheritance of $\mathrm{FH}$; extent of elevation in risk of CVD, definition of premature CVD, and physical features in $\mathrm{FH}$; whether the diagnosis requires genetic confirmation; methods for alerting PCPs about the possibility of FH; type of health professional best placed to detect $\mathrm{FH}$; number of patients with FH currently being treated; specific treatments; knowledge and practices concerning family screening; and treatment and referral practices regarding patients with severely elevated cholesterol. In addition, demographic data, including gender, qualifications and training status, years of experience, and size and location of practice, are recorded. The overall information generated by this project will ultimately 
Table 2. The research agenda for FH (adapted and modified from Gidding $\left.e a^{222}\right)$. Highlighted are research items that are being addressed in the "Ten Countries Study".

\begin{tabular}{|c|c|c|c|c|c|}
\hline Models of Care & Population Science & Basic Science & Life Course & Clinical Research & Patient-Centric Research \\
\hline $\begin{array}{l}\text { Better understand } \\
\text { patient and family } \\
\text { perspective on living } \\
\text { with } \mathrm{FH} \text {, including } \\
\text { concerns about the } \\
\text { disease, medication, } \\
\text { and genetic testing }\end{array}$ & $\begin{array}{l}\text { Cost-effectiveness } \\
\text { studies that include } \\
\text { universal and/or cas- } \\
\text { cade screening meth- } \\
\text { ods; also include chil- } \\
\text { dren in risk/benefit } \\
\text { assessment }\end{array}$ & & $\begin{array}{l}\text { Better understand the } \\
\text { impact of pregnancy } \\
\text { on the natural history } \\
\text { of FH }\end{array}$ & $\begin{array}{l}\text { Identify and study } \\
\text { biomarkers that may } \\
\text { improve identifica- } \\
\text { tion of early athero- } \\
\text { sclerosis, risk predic- } \\
\text { tion, and drug } \\
\text { responsiveness }\end{array}$ & $\begin{array}{l}\text { Decision aids (ie, tools } \\
\text { to help children, young } \\
\text { adults, and adults think } \\
\text { through screening and } \\
\text { treatment decisions) }\end{array}$ \\
\hline
\end{tabular}

be employed to design effective teaching and training modules for PCPs in the care of FH.

\section{(4) Health Service Research: Comparison of Ser- vices and Facilities for the Care of FH}

Despite the increasing recognition of the importance of $\mathrm{FH}$, the care of patients and families remains suboptimal ${ }^{9,15)}$. Services need improvement and standardization at several levels ${ }^{18,43}$. This includes pediatric services, cascade screening, and multidisciplinary care that involves laboratory medicine, cardiology, and transfusion medicine. Close collaboration between healthcare systems, patient support groups, and nongovernment organizations is essential ${ }^{9)}$. A clinical registry can also provide invaluable information for research and audit as well as for improving the quality of care. There are no published data describing or comparing healthcare resources for the detection and management of $\mathrm{FH}$ across different countries with diverse healthcare systems. This project will provide knowledge that could form an international benchmark for future performance in the care of FH. The knowledge will be generated within a context that takes an account of cultural, economic, and logistic differences and will create opportunities for implementing country-specific or region-specific models of care for FH. It will promote regional and international collaboration that could greatly enhance the development of new services for $\mathrm{FH}$ where gaps are identified.

The project is based on an online questionnaire that specifically investigates the key dimensions of a desirable model of care ${ }^{9,44,45}$. This will be completed voluntarily by the main key opinion leaders or experts in $\mathrm{FH}$ in the region. The enquiry relates to the following elements: national guidelines and protocols, medical specialties involved in care, role of primary care, screening, diagnostic and assessment protocols, DNA testing facilities, pediatric services, therapeutic strategies, apheresis and liver transplantation; clinical support (nurses, dieticians, counsellors, information technology, and registry), biochemistry laboratory services, cardiology services, funding (public, private, health insurance), drug re-imbursement, education and training programs, research programs, links with and support from government and non-government organizations, and existence of a family support group ${ }^{9,43,45)}$. 


\section{(5) Health Psychology: Patient Perceptions and Personal Experiences of FH}

Numerous psychological factors have been found to be associated with salient adaptive outcomes and individual patient-related behaviors linked with successful treatment and management of $\mathrm{FH}^{46}$. Current research suggests that attitudes and beliefs about the severity of $\mathrm{FH}$ predict intentions and motivation to engage in treatment, particularly adherence to lipidlowering drug regimens and self-management behaviors such as physical activity and $\operatorname{diet}^{47)}$. However, much of the research has been conducted in relatively small samples using qualitative methods ${ }^{48)}$. Other additional psychological factors that may be related to important outcomes related to the management of illness should be investigated in $\mathrm{FH}$ patients. These include facilitating factors and barriers in compliance with behavioral therapy and lifestyle changes, particularly among those who do not have any clinical manifestation of the illness and are asymptomatic ${ }^{49)}$. In addition, factors that may affect adherence to treatment, including beliefs about the controllability of the illness and efficacy of medication, should be identified and investigated. This project will identify key psychological factors associated with adherence and patient decisions to consent to refer relatives for cascade testing for FH. The factors can then be used as a basis for behavioral interventions to promote better care of families with $\mathrm{FH}$.

Participants will be recruited from regional clinics managing $\mathrm{FH}$ patients in different countries. Volunteer patients with $\mathrm{FH}$ will be recruited via clinic staff who will offer them the opportunity to participate. The study will adopt a correlational, quantitative design, in which psychometric measures of key psychological and behavioral variables will be elicited from samples of FH patients. The factors include attitudes, motives, and beliefs toward treatment, including drug and self-management behaviors, beliefs in medication, FH illness perceptions, and health literacy. Measures will be based on previous research and will be informed by a preliminary qualitative study ${ }^{50)}$. Key clinical and behavioral outcomes will also be collected from patient records in the collaborating clinics. Language-specific versions of the questionnaire will be developed from the English-language version using standardized back-translation techniques with the aid of bilingual translators. Comparisons of the key psychological correlates of treatment and management behaviors and outcomes across the different countries is of particular interest because it will facilitate understanding of the cultural influences on living with, treating, and managing $\mathrm{FH}$.

A pilot study in Australia ${ }^{51)}$ has demonstrated that patient attitudes and beliefs toward treatment and behaviors rather than beliefs about the illness are the key determinants of intentions to engage in treatment and self-management behaviors, suggesting that changing attitudes and beliefs toward the behaviors is a priority for promoting better management of $\mathrm{FH}$. We plan to investigate and compare the effects of these psychological factors on behaviors and outcomes among the participating countries.

\section{Conclusion and Future Perspective}

The "Ten Countries Study" is the first collaborative effort relating to $\mathrm{FH}$ in countries in Asia and the southern hemisphere. A series of five studies will garner new knowledge that is likely to enhance the care of patients and families with $\mathrm{FH}$ in a region that has the highest density of people with the condition. The projects are aligned with the research agenda recently proposed in a Scientific Statement by the American Heart Association (AHA) ${ }^{22)}$. The complete collection of data and analyses will be completed in the second half of 2016; some findings have already been published $^{32,33,37,51)}$. The future will hopefully see the extension of the projects to other countries, piloting of a regional web-based registry (including a pediatric registry ${ }^{52)}$ ), updating international guidelines, and developing a wider research agenda within the remit proposed by the AHA ${ }^{22)}$. Transfer of the research findings to enhance the awareness and knowledge of $\mathrm{FH}$ among healthcare professionals is an essential future objective, including the incorporation and utilization of the findings into routine clinical practice. The wider impact and effectiveness of future studies relies on the development of closer collaborative efforts with other international initiatives, such as the FH Studies Collaboration (FHSC) ${ }^{21)}$ and the ScreenPro FH Proj$\mathrm{ect}^{53)}$. At country, region, and local levels, the instigation of partnership between clinical and political stakeholders and patient support groups is essential to effectively translate current and future evidence into better healthcare for all patients and families with $\mathrm{FH}^{54)}$.

\section{Acknowledgment}

We acknowledge the team members for the "Ten Countries Study": Devi Arikketh (India), Tester F Ashavaid (India), Nurul Atiqah (Malaysia), Shanthi Balasubramaniam (India), Dick C Chan (Australia), Nien-Tzu Chang (Taiwan), Thuy Can Do (Vietnam), Dong Zhao (China), Katrina L Ellis (Australia), Ki Hoon Han (South Korea), Sarah J Hardcastle (Australia), Cinthia E Jannes (Brazil), Alicezah Mohd Kassim 
(Malaysia), Zaliha Mohd Ismail (Malaysia), See Kwok (United Kingdom), Carolyn SP Lam (Singapore), Peter J Lansberg (the Netherlands), Michael Livingston (International FH Foundation), Manjeet Mehta (India), Lauretta Muir (New Zealand), Hoh Boon Peng (Malaysia), Alexandre C Pereira (Brazil), Thuhairah Hasrah Abdul Rahman (Malaysia), Anis Safura Ramli (Malaysia), Nandhini Rangarajan (India), Suraya Abdul Razak (Malaysia), Eric JG Sijbrands (the Netherlands), David R Sullivan (Australia), E Shyong Tai (Singapore), Hong Chan Tan (Singapore), Ishwar C Verma (India), Xue Wu (China).

\section{Disclosure}

Prof Santos has received honoraria and consulting fees from Amgen, Astra Zeneca, Biolab, Boehringer-Ingelheim, Eli-Lilly, Merck, Genzyme, Kowa, Sanofi/Regeneron, Torrent and Pfizer. Prof Santos has also received research grants from Amgen, Sanofi/ Regeneron and Genzyme. Prof Yamashita has received honoraria and consulting fees from Bayer, Kowa, Medicar Review, MSD, Sanwa-Kagaku, Skylight Biotec and Shionogi. Prof Yamashita has also received research grants from Japan Boehringer-Ingelheim, Kyowa Medex, Otsuka and scholarship grants from Astra Zeneca, Bayer, Japan Boehringer-Ingelheim, Kowa, Mochida, MSD, Ono, Sanwa-Kagaku and Takeda. All other authors declare no financial interests or potential conflicts of interest.

\section{Funding}

The "Ten Countries Study" was funded by the International Atherosclerosis Society (IAS) and Pfizer Independent Grants for Learning \& Change (Grant ID: 10839501), and is being undertaken under the aegis of the FH Australasia Network (FHAN) and the Australian Atherosclerosis Society (AAS) Inc. We thank Ms Natasha Whitwell and Ms Jennifer Seabrook for their excellent assistance.

\section{References}

1) Austin MA, Hutter CM, Zimmern RL and Humphries SE: Genetic causes of monogenic heterozygous familial hypercholesterolaemia: A HuGE prevalence review. Am J Epidemiol, 2004; 160: 407-420

2) Marks D, Thorogood M, Neil HAW and Humphries SE: A review on the diagnosis, natural history, and treatment of familial hypercholesterolaemia. Atherosclerosis, 2003; 168: $1-14$

3) Goldstein JL, Schrott HG, Hazzard WR, Bierman EL and Motulsky AG: Hyperlipidemia in coronary heart disease II. Genetic analysis of lipid levels in 176 families and delineation of a new inherited disorder, combined hyperlipidemia. J Clin Invest, 1973; 52: 1544-1568

4) Goldstein JL, Hobbs HH and Brown MS: The Metabolic and Molecular Bases of Inherited Disease, McGraw-Hill Information Services Company, New York, 2001

5) Raal FJ and Santos RD: Homozygous familial hypercholesterolemia: Current perspectives on diagnosis and treatment. Atherosclerosis, 2012; 223: 262-268

6) Sjouke B, Kusters DM, Kindt I, Besseling J, Defesche JC, Sijbrands EJG, Roeters van Lennep JE, Stalenhoef AFH, Wiegman A, de Graaf J, Fouchier SW, Kastelein JJP and Hovingh GK: Homozygous autosomal dominant hypercholesterolaemia in the Netherlands: prevalence, genotype-phenotype relationship, and clinical outcome. Eur Heart J, 2014; ehu058

7) Pang J, Poulter EB, Bell DA, Bates TR, Jefferson V-L, Hillis GS, Schultz CJ and Watts GF: Frequency of familial hypercholesterolemia in patients with early-onset coronary artery disease admitted to a coronary care unit. J Clin Lipidol, 2015; 9: 703-708

8) Watts GF, Juniper A, van Bockxmeer F, Ademi Z, Liew D and O'Leary P: Familial hypercholesterolaemia: a review with emphasis on evidence for treatment, new models of care and health economic evaluations. Int J Evid Based Healthc, 2012; 10: 211-221

9) Watts GF, Gidding S, Wierzbicki AS, Toth PP, Alonso R, Brown WV, Bruckert E, Defesche J, Lin KK and Livingston $\mathrm{M}$ : Integrated Guidance on the Care of Familial Hypercholesterolaemia from the International FH Foundation. Int J Cardiol, 2014; 171: 309-325

10) Ademi Z, Watts GF, Juniper A and Liew D: A systematic review of economic evaluations of the detection and treatment of familial hypercholesterolemia. Int J Cardiol, 2013; 167: 2391-2396

11) Versmissen J, Oosterveer DM, Yazdanpanah M, Defesche JC, Basart DCG, Liem AH, Heeringa J, Witteman JC, Lansberg PJ, Kastelein JJP and Sijbrands EJG: Efficacy of statins in familial hypercholesterolaemia: a long term cohort study. Br Med J, 2008; 337: a2423

12) Neil A, Cooper J, Betteridge J, Capps N, McDowell I, Durrington P, Seed M, Humphries SE and on behalf of the Simon Broome Familial Hyperlipidaemia Register Group: Reductions in all-cause, cancer, and coronary mortality in statin-treated patients with heterozygous familial hypercholesterolaemia: a prospective registry study. Eur Heart J, 2008; 29: 2625-2633

13) Harada-Shiba M, Sugisawa T, Makino H, Abe M, Tsushima M, Yoshimasa Y, Yamashita T, Miyamoto Y, Yamamoto A, Tomoike $\mathrm{H}$ and Yokoyama S: Impact of statin treatment on the clinical fate of heterozygous familial hypercholesterolemia. J Atheroscler Thromb, 2010; 17: 667-674

14) Raal FJ, Pilcher GJ, Panz VR, van Deventer HE, Brice BC, Blom DJ and Marais AD: Reduction in Mortality in Subjects With Homozygous Familial Hypercholesterolemia Associated With Advances in Lipid-Lowering Therapy. Circulation, 2011; 124: 2202-2207

15) Nordestgaard BG, Chapman MJ, Humphries SE, Ginsberg HN, Masana L, Descamps OS, Wiklund O, Hegele RA, Raal FJ and Defesche JC: Familial hypercholesterolaemia is underdiagnosed and undertreated in the general 
population: guidance for clinicians to prevent coronary heart disease Consensus Statement of the European Atherosclerosis Society. Eur Heart J, 2013; 34: 3478-3490

16) Arai H, Ding Y-A and Yamashita S: Impact of the Integrated Guidance on the Care of Familial Hypercholesterolaemia. J Atheroscler Thromb, 2014; 21: 366-374

17) Harada-Shiba M, Arai H, Oikawa S, Ohta T, Okada T, Okamura T, Nohara A, Bujo H, Yokote K and Wakatsuki A: Guidelines for the management of familial hypercholesterolemia. J Atheroscler Thromb, 2012; 19: 1043-1060

18) Watts GF, Sullivan DR, Poplawski N, van Bockxmeer F, Hamilton-Craig I, Clifton PM, O’Brien R, Bishop W, George P, Barter PJ, Bates T, Burnett JR, Coakley J, Davidson P, Emery J, Martin A, Farid W, Freeman L, Geelhoed E, Juniper A, Kidd A, Kostner K, Krass I, Livingston M, Maxwell S, O'Leary P, Owaimrin A, Redgrave TG, Reid N, Southwell L, Suthers G, Tonkin A, Towler S and Trent R: Familial hypercholesterolaemia: A model of care for Australasia. Atherosclerosis Supplements, 2011; 12: 221-263

19) Hu M, Hooper AJ, Bockxmeer FMv, Watts GF, Chan JC and Tomlinson B: Management of Familial Hypercholesterolemia in Hong Kong. J Atheroscler Thromb, 2016; 23: $520-531$

20) Lee SH: Characteristics and Vascular Complications of Familial Hypercholesterolemia in Korea. J Atheroscler Thromb, 2016; 23: 532-538

21) Vallejo-Vaz AJ, Kondapally Seshasai SR, Cole D, Hovingh GK, Kastelein JJP, Mata P, Raal FJ, Santos RD, Soran H, Watts GF, Abifadel M, Aguilar-Salinas CA, Akram A, Alnouri F, Alonso R, Al-Rasadi K, Banach M, Bogsrud MP, Bourbon M, Bruckert E, Car J, Corral P, Descamps O, Dieplinger H, Durst R, Freiberger T, Gaspar IM, Genest J, Harada-Shiba M, Jiang L, Kayikcioglu M, Lam CSP, Latkovskis G, Laufs U, Liberopoulos E, Nilsson L, Nordestgaard BG, O’Donoghue JM, Sahebkar A, Schunkert H, Shehab A, Stoll M, Su T-C, Susekov A, Widén E, Catapano AL and Ray KK: Familial hypercholesterolaemia: A global call to arms. Atherosclerosis, 2015; 243: 257-259

22) Gidding SS, Champagne MA, de Ferranti SD, Defesche J, Ito MK, Knowles JW, McCrindle B, Raal F, Rader D, Santos RD, Lopes-Virella M, Watts GF and Wierzbicki AS: The Agenda for Familial Hypercholesterolemia - A Scientific Statement From the American Heart Association. Circulation, 2015; 132: DOI: 10.1161/CIR.0000000000000297

23) Soutar AK and Naoumova RP: Mechanisms of Disease: genetic causes of familial hypercholesterolemia. Nat Clin Pract Cardiovasc Med, 2007; 4: 214-225

24) Hooper AJ, Nguyen LT, Burnett JR, Bates TR, Bell DA, Redgrave TG, Watts GF and van Bockxmeer FM: Genetic analysis of familial hypercholesterolaemia in Western Australia. Atherosclerosis, 2012; 224: 430-434

25) Khera AV, Won H-H, Peloso GM, Lawson KS, Bartz TM, Deng X, van Leeuwen EM, Natarajan P, Emdin CA, Bick AG, Morrison AC, Brody JA, Gupta N, Nomura A, Kessler T, Duga S, Bis JC, van Duijn CM, Cupples LA, Psaty B, Rader DJ, Danesh J, Schunkert H, McPherson R, Farrall $\mathrm{M}$, Watkins $\mathrm{H}$, Lander E, Wilson JG, Correa A, Boerwinkle E, Merlini PA, Ardissino D, Saleheen D, Gabriel S and Kathiresan S: Diagnostic Yield of Sequencing Familial Hypercholesterolemia Genes in Patients with Severe
Hypercholesterolemia. J Am Coll Cardiol, 2016; 10.1016/ j.jacc.2016.1003.1520

26) Goldberg AC, Hopkins PN, Toth PP, Ballantyne CM, Rader DJ, Robinson JG, Daniels SR, Gidding SS, de Ferranti SD, Ito MK, McGowan MP, Moriarty PM, Cromwell WC, Ross JL and Ziajka PE: Familial Hypercholesterolemia: Screening, diagnosis and management of pediatric and adult patients: Clinical guidance from the National Lipid Association Expert Panel on Familial Hypercholesterolemia. J Clin Lipidol, 2011; 5: 133-140

27) Shin DG, Han SM, Kim DI, Rhee M-Y, Lee B-K, Ahn YK, Cho BR, Woo J-T, Hur S-H, Jeong J-O, Jang Y, Lee $\mathrm{JH}$ and Lee S-H: Clinical features of familial hypercholesterolemia in Korea: Predictors of pathogenic mutations and coronary artery disease - A study supported by the Korean Society of Lipidology and Atherosclerosis. Atherosclerosis, 2015; 243: 53-58

28) Haralambos K, Whatley SD, Edwards R, Gingell R, Townsend D, Ashfield-Watt P, Lansberg P, Datta DBN and McDowell IFW: Clinical experience of scoring criteria for Familial Hypercholesterolaemia $(\mathrm{FH})$ genetic testing in Wales. Atherosclerosis, 2015; 240: 190-196

29) Muir LA, George PM, Laurie AD, Reid N and Whitehead L: Preventing cardiovascular disease: a review of the effectiveness of identifying the people with familial hypercholesterolaemia in New Zealand. N Z Med J, 2010; 123: 97-102

30) Laurie AD, Scott RS and George PM: Genetic screening of patients with familial hypercholesterolaemia $(\mathrm{FH})$ : a New Zealand perspective. Atherosclerosis Supplements, 2004; 5: 13-15

31) Goldberg AC and Gidding SS: Knowing the Prevalence of Familial Hypercholesterolemia Matters. Circulation, 2016; 133: 1054-1057

32) Shi Z, Yuan B, Zhao D, Taylor AW, Lin J and Watts GF: Familial hypercholesterolemia in China: Prevalence and evidence of underdetection and undertreatment in a community population. Int J Cardiol, 2014; 174: 834-836

33) Watts GF, Shaw JE, Pang J, Magliano DJ, Jennings GLR and Carrington MJ: Prevalence and treatment of familial hypercholesterolemia in Australian communities. Int J Cardiol, 2015; 185: 69-71

34) de Ferranti SD, Rodday AM, Mendelson MM, Wong JB, Leslie LK and Sheldrick RC: Prevalence of Familial Hypercholesterolemia in the 1999 to 2012 United States National Health and Nutrition Examination Surveys (NHANES). Circulation, 2016; 133: 1067-1072

35) Benn M, Watts GF, Tybjærg-Hansen A and Nordestgaard BG: Mutations causative of familial hypercholesterolaemia: screening of 98098 individuals from the Copenhagen General Population Study estimated a prevalence of 1 in 217. Eur Heart J, 2016; 10.1093/eurheartj/ehw1028

36) Benn M, Watts GF, Tybjaerg-Hansen A and Nordestgaard BG: Familial Hypercholesterolemia in the Danish General Population: Prevalence, Coronary Artery Disease, and Cholesterol-Lowering Medication. J Clin Endocrinol Metab, 2012; 97: 3956-3964

37) Pang J, Martin AC, Mori TA, Beilin LJ and Watts GF: Prevalence of familial hypercholesterolaemia in adolescents: potential value of universal screening? The Journal of Pediatrics, 2016; 170: 315-316 
38) De Backer G, Besseling J, Chapman J, Hovingh GK, JJP K, Ray K, Reiner Z, Wood D and De Bacquer D: Prevalence and management of familial hypercholesterolaemia in coronary patients: an analysis of EUROASPIRE IV. Atherosclerosis, 2015; 241: 169-175

39) Kirke A, Watts GF and Emery J: Detecting familial hypercholesterolaemia in general practice. Aust Fam Physician, 2012; 41: 965-968

40) Qureshi N, Humphries SE, Seed M, Rowlands P, Minhas $\mathrm{R}$ and NICE Guideline Development Group: Identification and management of familial hypercholesterolaemia: what does it mean to primary care? Br J Gen Pract, 2009; 59: 773-778

41) Bell DA, Garton-Smith J, Vickery A, Kirke A, Pang J, Bates TR and Watts GF: Familial Hypercholesterolaemia in Primary Care: Knowledge and Practices Among General Practitioners in Western Australia. Heart, Lung and Circulation, 2014; 23: 309-313

42) Pang J, Sullivan DR, Harada-Shiba M, Ding PY, Selvey S, Ali $S$ and Watts GF: Significant gaps in awareness of familial hypercholesterolemia among physicians in selected Asia-Pacific countries: A pilot study. J Clin Lipidol, 2015; 9: $42-48$

43) Datta BN, McDowell IF and Rees A: Integrating provision of specialist lipid services with cascade testing for familial hypercholesterolaemia. Curr Opin Lipidol, 2010; 21: 366-371

44) National Institute for Health and Clinical Excellence and The National Collaborating Centre for Primary Care: NICE Clinical Guideline 71: Identification and management of familial hypercholesterolaemia. 2008;

45) Pedersen KMV, Humphries SE, Roughton M and Besford JS: The National Audit of the Management of Familial Hypercholesterolaemia 2010: Full report. 2010;

46) Claassen L, Henneman L, Kindt I, Marteau TM and Timmermans DRM: Perceived Risk and Representations of Cardiovascular Disease and Preventive Behaviour in People Diagnosed with Familial Hypercholesterolemia. J Health Psychol, 2010; 15: 33-43

47) Hollman G, Olsson AG and Ek A-C: Disease knowledge and adherence to treatment in patients with familial hypercholesterolemia. J Cardiovasc Nurs, 2006; 21: 103-108

48) Weiner K and Durrington PN: Patients' understandings and experiences of familial hypercholesterolemia. Public Health Genomics, 2008; 11: 273-282

49) Muir LA, George PM and Whitehead L: Using the experiences of people with familial hypercholesterolaemia to help reduce the risk of cardiovascular disease: a qualitative systematic review. J Adv Nurs, 2012; 68: 1920-1932

50) Hardcastle SJ, Legge E, Laundy CS, Egan SJ, French R, Watts GF and Hagger MS: Patients' Perceptions and Experiences of Familial Hypercholesterolemia, Cascade Genetic Screening and Treatment. International Journal of Behavioral Medicine, 2015; 22: 92-100

51) Hagger MS, Hardcastle SJ, Hingley C, Strickland E, Pang $J$ and Watts GF: Predicting Self-Management Behaviors in Familial Hypercholesterolemia Using an Integrated Theoretical Model: the Impact of Beliefs About Illnesses and Beliefs About Behaviors. International Journal of Behavioral Medicine, 2016; 23: 282-294

52) Ramaswami U, Cooper J and Humphries SE: The UK Paediatric Familial Hypercholesterolaemia Register: preliminary data. Arch Dis Child, 2016; 10.1136/archdischild-2015-308570

53) Screening Project for Familial Hypercholesterolemia in Central, Southern and Eastern Europe. 2015; http:// screenprofh.com/

54) Pang J, Lansberg PJ and Watts GF: International Developments in the Care of Familial Hypercholesterolemia: Where Now and Where to Next? J Atheroscler Thromb, 2016; 23: 505-519 